\title{
Damage from the larkspur mirid deters cattle grazing of larkspur
}

\author{
MICHAEL H. RALPHS, WALKER A. JONES, AND JAMES A. PFISTER
}

Authors are rangeland scientist, USDAVARS Poisonous Plant Lab., 1150 E. 1400 N., Logan, Ut. 84341; entomologist, USDA/ARS Biological Control of Pests, Weslaco, Tex. 78596; and rangeland scientist, USDA/ARS Poisonous Plant Lab, Logan, Ut.

\begin{abstract}
The larkspur mirid (Hopplomachus affiguratus) is host specific to tall larkspur (Delphinium barbeyi Huth). These insects suck cell solubles from leaves and reproductive racemes, causing flowers to abort and leaves to desiccate. Cattle generally prefer larkspur flowering heads, pods, and leaves, and are frequently poisoned. The objective of this experiment was to determine if cattle would avoid eating mirid-damaged larkspur. A 2-choice cafeteria feeding trial was conducted to determine preference for miriddamaged and undamaged larkspur. Four cows were offered a choice of the 2 types of larkspur in 10 min. feeding trials in the morning and evening for 5 days. Cows preferred the undamaged larkspur plants $(0.8 \mathrm{~kg} \pm 0.08, \mathrm{SE})$ over mirid-damaged plants $(0.1 \mathrm{~kg} \pm 0.03, \mathrm{SE})$. The cows were then turned out into a larkspur-infested pasture and consumption of mirid-damaged and undamaged larkspur was quantified by bite count. The cows did not select any mirid-damaged larkspur. Consumption of undamaged larkspur peaked at $17 \%$ of bites on the second day of the grazing trial, then declined as mirid damage on the plants increased. If the density of mirids on larkspur is sufficiently high to damage most of the leaves and flowering racemes, grazing by cattle may be deterred, and subsequent poisoning avoided.
\end{abstract}

Key Words: biological control, Hopplomachus affiguratus, cattle poisoning, Delphinium barbeyi

Larkspurs (Delphinium spp.) kill more cattle on mountain rangelands than any other poisonous plant, disease or predator (Kingsbury 1964, Nielsen and Ralphs 1988). The larkspur mirid [Hopplomachus affiguratus (Heteroptera: Miridae)] is a native insect that is host specific to tall larkspur (Delphinium barbeyi Huth) (Uhler 1895, Fitz 1972), and may provide a biological tool to reduce the risk of larkspur poisoning in cattle. The larkspur mirid is a sucking insect that extracts cell solubles from immature, rapidly growing plant parts. The insects concentrate on the flowering racemes, causing the buds to abort; and also damage the leaves which first appear mottled, then desiccate and senesce.

\footnotetext{
The authors wish to thank Dr. Nancy Peterson and Connie Clementson for recognizing the potential of the larkspur mirid as a hiological tool, and their persistence and encouragement to initiate research. Thanks also to Lee Woolsey and Rob Pate for collecting data.

Manuscript accepted 2 Jul. 1996.
}

These are the larkspur plant parts normally preferred by cattle (Pfister et al. 1988).

Peterson and Clementson (1989) observed dense mirid populations that apparently reduced the vigor of a tall larkspur population in western Colorado, and proposed the use of the larkspur mirid as a biological control for larkspur. However, classical biological control theory suggests there is limited potential for a native insect to control a native plant because they have evolved together and both have developed adaptive mechanisms for survival. The objective of this research was not necessarily to kill or control larkspur, but rather investigate the potential of the larkspur mirid to damage tall larkspur and render it distasteful to cattle. Our hypothesis was that cattle would not consume miriddamaged larkspur.

\section{Methods}

\section{Site Description}

An existing larkspur mirid population was identified in a 3 ha larkspur patch near Ferron Reservoir on the Wasatch Plateau in central Utah. The site was in the subalpine zone $(3,000 \mathrm{~m}$ elevation) with scattered subalpine fir pockets interspersed in the tall forb plant community dominated by tall larkspur, western cone flower (Rudbeckia occidentalis Nutt.), sweetcicely (Osmorhiza occidentalis [Nutt.] Torr.), and mountain brome (Bromus carinatus Hooker \& Arn.). All of the larkspur plants in the patch were infested with mirids and had visibly damaged reproductive racemes and leaves. We estimated the average mirid density by counting the number of mirids on 3 leaves of 5 plants, and extrapolated from these plants to the general population of the patch.

\section{Pen Feeding Trial}

Four cows ( 3 Hereford and 1 Angus, $400 \mathrm{~kg}$ ) that had been grazing tall larkspur in a previous experiment in Salina Canyon (Pfister et al. 1997) were used in this study. Undamaged larkspur was in full flower. Mirid-damaged and undamaged larkspur plants were harvested daily and fed to the cows in a 2-choice cafeteria trial. Only $25 \%$ of each infested plant was harvested to preserve the mirid population. The harvested stems were gently shaken to remove the mirids onto the remaining portions of the plant. Heavily infested leaves typically are covered with black dots of fecal material, but summer thunder storms occurred 
before the study and washed all insect fecal material off the leaves. Therefore, neither the mirids nor their fecal material directly influenced the taste of the damaged plants.

Two feeding pens ( $3 \mathrm{~m}$ by $4 \mathrm{~m}$ ) were partitioned within a larger corral to allow 2 cows to be fed separately at the same time. Two, 80 liter tubs were placed in each pen to hold the $1-\mathrm{m}$ tall larkspur stalks upright. The location of the damaged and undamaged larkspur was alternated at each feeding to eliminate location bias. Two to $3 \mathrm{~kg}$ of damaged and undamaged larkspur were weighed and placed in each tub and the cows were allowed to eat for 10 min. The uneaten portion was weighed and consumption was calculated for each cow. The feeding trials were conducted each morning and evening for 5 consecutive days. Following each larkspur feeding, the cows were fed half their daily ration of certified weed-seed-free alfalfa hay $(9 \mathrm{~kg})$. A sample of the larkspur stalks at the end of the trial was weighed, then dried in a forced air oven $\left(60^{\circ} \mathrm{C}\right.$ for 48 hours) to determine dry matter content. The leaves were then plucked from the stems and analyzed for crude protein by the Kjeldahl total nitrogen method (AOAC 1965), and cell walls by neutral detergent fiber analysis (NDF, Goering and Van Soest 1970).

Consumption of damaged and undamaged larkspur was averaged over the 5 days for each of the 4 cows, then the average consumption was compared by a paired t-test. Also, a preference ratio (PR) for the undamaged larkspur was calculated: $P R=$ undamaged/(undamaged + damaged). A 1-tailed t-test was used to determine if the preference ratio for undamaged larkspur differed significantly from the neutral preference of 0.5 .

\section{Grazing Trial}

Following the pen trial, the cows were turned out into a 1.1 ha larkspur-infested pasture and allowed to graze freely for 15 days. Diets were quantified by bite count. Each cow was observed for 5 min intervals during the major daily grazing periods, and the number of bites of each forage class was counted (mirid-damaged larkspur, undamaged larkspur, other forbs, and grass). Four to 8 observations were made of each cow daily through the major grazing periods. Standing crop of forage classes was clipped from ten $1 \times .25 \mathrm{~m}$ quadrats systematically placed at 20 step intervals along a paced transect through the middle of the pasture. These were dried in a forced air oven at $60^{\circ}$ for 48 hours and weighed.

All larkspur plants in the pasture were infested with mirids. However, infestation and damage began on the south-east quarter of the plants (the preferred spatial orientation for mirids) then spread throughout the plant as the season progressed. A visual assessment was made of the percentage of flowering heads aborted and the percentage of leaf biomass damaged by mirids. At the beginning of the trial, approximately half of each plant was damaged. Thus, the comparison was made between cattle bites of damaged vs. undamaged plant parts.

The percentage of bites of damaged and undamaged larkspur was transformed by arcsin and analyzed in a general linear model (SAS 1988) in a split plot design over days. The type of larkspur was the main plot and was tested by the type $X$ cow interaction. Day was the split plot and day and the day $x$ type interaction were tested by the residual error. The untransformed mean daily bites of damaged and undamaged larkspur ( \pm SE) were plotted.

Larkspur consumption by the cows while they were on the previous larkspur grazing study was also presented as a comparison of intake of undamaged larkspur.

\section{Results and Discussion}

\section{Pen Feeding Trial}

Cattle preferred the undamaged tall larkspur $(P=0.007)$, consuming an average of $0.8 \mathrm{~kg}$ ( $\pm .08 \mathrm{SE}$ ) during the 10 min.feeding periods, compared to $0.1 \mathrm{~kg}$ ( $\pm .03 \mathrm{SE}$ ) of the mirid-damaged larkspur. The preference ratio for undamaged plants was 0.90 , which differed from neutral preference of $0.5(P<0.01)$. Most consumption of the mirid-damaged plants occurred at the beginning of the feeding periods when cows went first to the tubs containing damaged larkspur. After switching to the undamaged larkspur, they seldom went back to the damaged larkspur. Their behavior portrayed a clear preference for the undamaged larkspur.

Dry matter content of the mirid-damaged plants was slightly higher than the undamaged plants ( 20 vs. $17 \%)$, indicating that the aborted flowering heads and damaged leaves of the mirid-damaged plants were not as succulent as the undamaged plants. Crude protein content of the mirid-damaged leaves was lower than the undamaged leaves (16.9 vs $22.3 \%$ ), but NDF was similar (31.8 vs $32.5 \%$ ). Perhaps normal cell wall development was arrested in mirid-damaged plants, thus limiting fiber deposition. In a companion study, we found that damage from the larkspur mirid did not alter toxic or total alkaloid levels in tall larkspur plants (Ralphs et al. 1997), thus the mirids are likely to not affect toxicity or palatability associated with alkaloid levels. Further research is necessary to identify the nutrient and palatability factors responsible for the reduced acceptability of mirid-damaged larkspur.

\section{Field Grazing Trial}

Larkspur comprised $27 \%$ of the standing crop in the experimental pasture (Table 1). The cows did not consume mirid-damaged portions of larkspur plants in the pasture, but consumed undamaged larkspur for an average of $3 \%$ of bites (Table $1, P=0.12$ ).

Table 1. Standing crop of forage clasces in the experimental pasture and percentage of bites of forage consumed by cattle ( \pm SE).

\begin{tabular}{|c|c|c|}
\hline $\begin{array}{l}\text { Forage } \\
\text { class }\end{array}$ & $\begin{array}{l}\text { Standing } \\
\text { crop }\end{array}$ & $\begin{array}{c}\text { Percentage } \\
\text { of bites }\end{array}$ \\
\hline $\begin{array}{l}\text { Larkspur } \\
\text { mirid-damaged } \\
\text { undamaged }\end{array}$ & $\begin{array}{c}401 \pm 246\end{array}$ & $\begin{array}{c}0(\%) \cdots \\
0 \\
3 \pm 0.6\end{array}$ \\
\hline $\begin{array}{l}\text { Other } \\
\text { forbs }\end{array}$ & $878 \pm 163$ & $57 \pm 1$ \\
\hline Grass & $190 \pm 40$ & $40 \pm 1$ \\
\hline
\end{tabular}

However, there was a larkspur type $X$ day interaction $(P<0.01)$. Cattle consumed uninfested larkspur for $17 \%$ of bites on the second day of the trial, after which larkspur consumption steadily declined (Fig 1). The decline in larkspur consumption was apparently due to the progressive damage from the mirids. At the beginning of the trial, about half of each plant was damaged. Leaves on the northwest quarter of the plants were generally undamaged and were grazed by cattle. As the trial progressed, mirids moved into the non-infested parts and continued inflicting damage, thus rendering the remaining parts of the larkspur plants unpalatable. By the end of the trial, all of the larkspur reproductive heads had aborted or were grazed. 


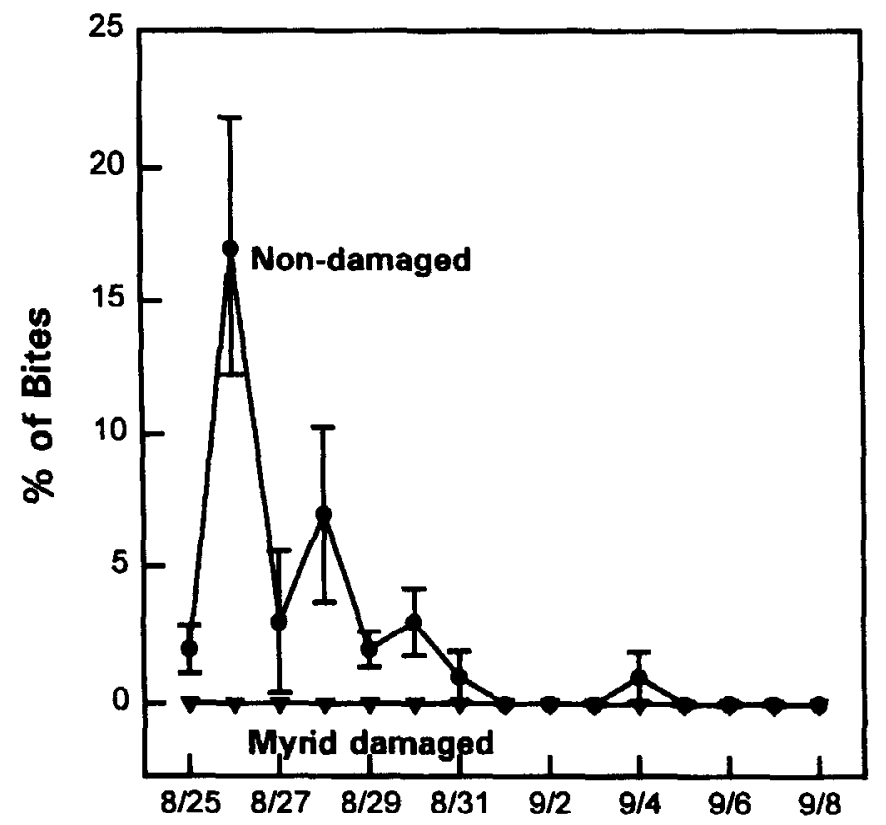

Date

Fig. 1. Mean daily consumption ( $\%$ of bites \pm SE) by cattle of miriddamaged and undamaged tall larkspur in the field grazing trial.

These same cows consumed larkspur for $4 \%$ of bites in the previous larkspur grazing trial at Salina Canyon (Pfister et al. 1997). In a series of 7 larkspur grazing studies between 1986 and 1990 in the same vicinity, larkspur consumption averaged $7 \%$ of bites (Ralphs and Pfister 1992), but reached as high as $80 \%$ of bites in some grazing periods. Cattle generally increase larkspur consumption as it matures from the flower into the pod stage (Pfister et al. 1988).

We cstimated the mirid density on the study site at about 10,000 mirids per plant. There was an average of 90 mirids/leaf on the younger leaves on the upper half of the stem (6 leaves/stem), on about half the stems of each plant ( 20 stems/plant) at a given time. This density of mirids caused $100 \%$ of flowering heads to abort, and damaged $83 \%$ of leaf biomass on plants adjacent to the study pasture (unpublished data).

Another dense population of the larkspur mirid exists in the Bull Park area $18 \mathrm{~km}$ southwest of Yampa, Colo. This mirid population has been monitored since 1986, and has experienced dramatic cycles in mirid density. Over that period, the larkspur population declined in vigor and density, and the rancher observed a decline in cattle deaths in that area (Nancy Peterson, personal communication). This suggests that even though the mirids are native insects, they may be able to suppress larkspur over time if their populations remain high. We will continue to monitor the mirid populations at Yampa and Ferron Reservoir and measure their impact on larkspur vigor and density over time.

\section{Conclusions}

Cattle preferred undamaged larkspur plants in the pen feeding trial, and did not eat mirid-damaged portions of larkspur plants in the field grazing trial. Cattle initially consumed the undamaged portions of larkspur plants at the beginning of the grazing trial, but larkspur consumption declined and ceased as mirid-damage increased. These results confirm our previous observations that cattle will not graze mirid-damaged portions of larkspur plants.

The larkspur mirid occurs in most tall larkspur populations we have observed; however, their density is generally low. Infestation and propagation techniques must be developed to enhance these natural populations if the larkspur mirid is to be used as a biological tool to reduce cattle poisoning. We infested new areas by transporting both young nymphs, and eggs in senescent stems, which subsequently damaged the newly infested plants (Jones and Ralphs 1997a). We also described the over wintering requirements for eggs in stems, and measured hatch rates (7 nymphs per inch of stem, Jones and Ralphs 1997b). Further research is necessary on the biology of the larkspur mirid to determine the environmental conditions that limit or constrain its populations, and determine if populations can spread throughout a larkspur patch and increase to a level that will significantly damage the larkspur plants. If the density of mirids described in this paper can be achieved in larkspur patches that persistently cause cattle deaths, then cattle may be deterred from grazing larkspur and the risk of poisoning will be substantially reduced.

\section{Literature Cited}

AOAC. 1990. Official Methods of Analysis. 15th Ed. Association of Official Agricultural Chemists. Arlington, Virg.

Fitz, F.K. 1972. Plant-insect interactions, tall larkspur, and biological control. pp 436-463, In: J.A. Behnke (ed), Challenging Biological Problems, Directions to Their Solutions. Oxford Univ. Press.

Goering, H.K and P.J. Van Soest. 1970. Forage Fiber Analysis. USDA/ARS Handb. 379.

Jones, W.A. and M.H. Ralphs. 1997a. Effects of Hopplomachus affiguratus (Heteroptera: Miridae) feeding on growth and development of tall larkspur Delphinium barbeyi (Ranunculaceae). Biological Control (in review).

Jones, W.A. and M.H. Ralphs. 1997b. Diapausing eggs of Hopplomachus affiguratus (Heteroptera: Miridae): oviposition site preference, winter survival, and eclosion in the poisonous weed Delphinium barbeyi (Ranunculaceae). Enviro. Entomol. (in review).

Kingsbury, J.M. 1964. Poisonous Plants of the United States and Canada. Prentice-Hall, Englewood Cliffs, N.J.

Nielsen, D.B. and M.H. Ralphs. 1978. Larkspur: economic considerations. pp 119-130, In: L.F. James, M.H. Ralphs and D.B. Nielsen (eds); The Ecology and Economic Impact of Poisonous Plants on Livestock Production. Westview Press, Boulder Colo.

Peterson, N. and C. Clementson. 1989. Larkspur losses-can nature help? Cattle Guard, Feb. 1989, Colo. Cattlemens Assoc., Denver Colo.

Pfister, J.A., M.H. Ralphs, and G.D. Manners. 1988. Cattle grazing tall larkspur on Utah mountain rangeland. J. Range Manage. 41:118-122.

Pfister, J.A., M.H. Ralphs, G.D. Manners, K. Price, and L.F. James. 1997. Early season grazing by cattle of tall larkspur (Delphinium spp.) rangelands. J. Range Manage. 50:391-398.

Ralphs, M.H. and J.A. Prister. 1992. Cattle diets in tall forb communities on mountain rangelands. J. Range Manage. 45:534-537.

Ralphs, M.H., W.A. Jones, G.D. Manners, and D.R. Gardner. 1997. Alkaloid concentration in tall larkspur plants damaged by the larkspur mirid. J. Chem, Ecol. (in review).

SAS. 1988. SAS/STAT Users Guide (6.04). SAS Inst. Inc., Cary, N.C.

Uhler P.R. 1895. Descriptions of new species. pp. 1-37. In: C.P. Gillete and C.F. Baker (Eds). A preliminary list of the Hemiptera of Colorado. Colo. Agr. Exp. Sta. Bull. 31 . 